\title{
Causes of death of domestic cats in a veterinary hospital of Uberlândia, Minas Gerais state: a retrospective study
}

\section{Causas de óbito em gatos domésticos em um hospital veterinário de Uberlândia, Minas Gerais: estudo retrospectivo}

\author{
Solangge Cristina RODRIGUES ${ }^{1}$; Thaís de Almeida MOREIRA ${ }^{1}$; Fernanda Gatti Oliveira NASCIMENTO루 ${ }^{1}$ Willian \\ Torres BLANCA ${ }^{1}$; Rafael Rocha de SOUZA ${ }^{1}$; Alessandra Aparecida MEDEIROS-RONCHI ${ }^{1}$ \\ ${ }^{1}$ Universidade Federal de Uberlândia, Faculdade de Medicina Veterinária, Uberlândia - MG, Brazil
}

\begin{abstract}
Cats play an important role as pets in the present society. Thus, the knowledge about their main diseases and causes of death is fundamental to prevent various pathologies. However, when dealing with domestic cats there are very few researches in Veterinary Medicine. The aim of this study is to identify the causes of death of cats through a retrospective study of necropsies in the Animal Pathology Laboratory in the Federal University of Uberlândia (Brazil), in a period of 36 years, in which 350 cat necropsies were conducted. The most frequent causes of death of these animals were digestive system diseases (48 cats - 13.71\%), and among them, feline hepatic lipidosis was the most frequent etiology (18.75\%). The second most affected system was the respiratory (10.86\%) and acute pneumonia, pulmonary edema, and diaphragmatic hernia were the main diseases to cause death of cats with some kind of disorder in this system. Other decease causes were rabies, squamous cell carcinoma, fibrous osteodystrophy, fractures and traumatism, hypovolemic shock, and feline lower urinary tract disease. This type of analysis can provide basic information about the most common diseases in felines, contributing with veterinarians as they adopt control and prevention actions against diseases.
\end{abstract}

Keywords: Felines. Death. Necropsy. Diseases.

\section{Resumo}

Os gatos apresentam papel relevante como animal de estimação na sociedade atual. Neste sentido, o conhecimento das principais enfermidades e causas de morte desses animais é fundamental para prevenção de várias patologias. No entanto, quanto ao gato doméstico, essas pesquisas ainda são escassas na medicina veterinária. Assim, este trabalho realizou um estudo retrospectivo das causas de morte de gatos registradas das necropsias efetuadas pelo Laboratório de Patologia Animal da Universidade Federal de Uberlândia, em um período de 36 anos, no qual 350 gatos foram necropsiados. As doenças do sistema digestivo foram as mais frequentes (48 gatos - 13,71\%) e destas, a lipidose hepática foi a etiologia de maior ocorrência (18,75\%). O sistema respiratório foi o segundo mais afetado (10,86\%), sendo pneumonia aguda, edema pulmonar e hérnia diafragmática as principais doenças deste sistema responsáveis pela morte de gatos. Outras causas de óbito importantes foram raiva, carcinoma de células escamosas, osteodistrofia fibrosa, fraturas e traumatismos, choque hipovolêmico e síndrome urológica felina. Este tipo de análise pode fornecer informações básicas sobre as enfermidades que mais acometem os felinos de uma determinada região, contribuindo para que os profissionais médicos veterinários passem a adotar as respectivas ações de prevenção e controle.

Palavras-chave: Felinos. Óbito. Necropsia. Doenças.

Correspondence to:

Thaís de Almeida Moreira

Universidade Federal de Uberlândia, Faculdade de

Medicina Veterinária

Av. Mato Grosso, 3225

CEP 38405-314, Uberlândia, MG, Brazil

e-mail: thais-vet@outlook.com

Received: 05/01/2017

Approved: 27/07/2017

\section{Introduction}

Life expectancy of cats has been increasing considerably in the last years. Therefore, the knowledge of the main diseases that affect these animals and lead them to death is extremely important (TRAPP et al., 2010). This type of information is fundamental for veterinarians, contributing with correct diagnosis and treatment, allowing prophylactic measures to reduce the death rate (TRAPP et al., 2010; 
LITTLE, 2015). Given this growing predominance of cats in households, studies about their causes of death have become increasingly urgent.

In England a study that presents data on longevity and causes of death of cats has been conducted (O'NEILL et al., 2014). However, in Brazil only causes of dog death have been well reported (BENTUBO et al., 2007; FIGHERA et al., 2008; GRIGALEVICIUS et al., 2015), while few studies have addressed this issue on cats and still have demonstrated controversies. Thus, only two studies (TRAPP et al. 2010; BATISTA et al., 2016) evaluated all the possible causes of death of cats in all ages. Nevertheless, in these studies, for Trapp et al. (2010), the main causes of death among cats are infectious diseases. For Batista et al. (2016), on the other hand, the cats have died mainly due to physical agents.

Further studies have addressed only the assessments made in a specific population of cats. This is the case for Manteigas et al. (2013), who have studied only cats over nine years old. In this specific population, chronic kidney disease (CKD - result of a variety of chronic injuries than can lead to nephron loss followed by adaptive hyperfiltration in the remaining nephrons) was reported as main cause of mortality. In addition, in another study carried out by Gonçalves (2010), only the causes of sudden death were evaluated. In this author's work, intoxications by carbamate, dicoumarol and organophosphorus compounds are cited as the most frequent causes of death.

Necropsy is the fundamental method for determining the cause of death. The description of all lesions and collection of material for further analysis (histopathology, toxicology examination, for example) are of extreme importance for a correct diagnosis (COARSEY; WOLDEMESKEL, 2017).

Therefore, this study aimed at evaluating the main causes of death of cats diagnosed in the Animal Pathology Laboratory in the Federal University of Uberlândia (Brazil), in a period of 36 years (from 1975 to 2011) to get 350 cats' necropsy medical records. As far as it is recorded, this is the first work addressing the causes of death of cats in a city of the state of Minas Gerais.

\section{Material and Methods}

Necropsy medical records of cats were selected, obtained from the archive of the Animal Pathology Laboratory in the Federal University of Uberlândia (Brazil, Minas Gerais State). Only properly recorded necropsies were chosen to the study. The number of individuals needed for sampling in such a study is estimated at 350 , as pointed by Thrusfield (2004).

Epidemiological data as gender, age, and breed were collected. The necroscopic reports were evaluated in each case and the cause of death recorded. Thus, the diagnostic method used was anatomopathological examination, considering all the complementary postmortem examinations performed in each case for definitive diagnosis, such as histopathological, toxicological, and immunohistochemical analysis.

In order to assess the necroscopic injuries, only the definitive diagnosis was considered, and when elucidating the cause of death was not possible, the diagnosis was considered inconclusive. The anatomopathological diagnoses obtained were combined according to the affected system and confronted with the current data in the literature.

\section{Results}

From 1975 to 2011, 350 cats were necropsied. Out of these, 159 (45.43\%) were male, 156 (44.57\%) were female and $35(10 \%)$ did not have information about gender. In terms of age, 122 animals (34.86\%) ranged from 0 to 12 months old, 63 animals (18\%) from 13 months to five years old, 26 cats $(7.43 \%)$ were from 6 to 10 years old, 20 animals (5.71\%) were more than 10 years old and 119 (34\%) did not have information about age. With this research, it was possible to verify a higher percentage of deaths in young animals.

When it comes to breed, 237 animals (67.71\%) were half-breed, 24 (6.86\%) were Siamese, 19 (5.42\%) were Persian, 14 (4.02\%) were Turkish Angora, one (0.28\%) was Brazilian Shorthair and 55 animals (15.71\%) did not have any information about breed. From this study, a higher rate of deaths in half-breed animals has been observed.

The distribution of systems directly related to the cause of death in the cats is shown in figure 1. Within the group of cats with the digestive system related to their cause of death, nine of them were affected by feline hepatic lipidosis. The second condition to affect the most cats in this present study was peritonitis, together with feline infectious peritonitis the most frequent (Table 1). The respiratory system was the second most common in causes of death of felines, and pneumonia was the main pathology, followed by pulmonary edema, diaphragmatic hernia, and bronchopneumonia (Table 2). 


\section{Affected Systems}

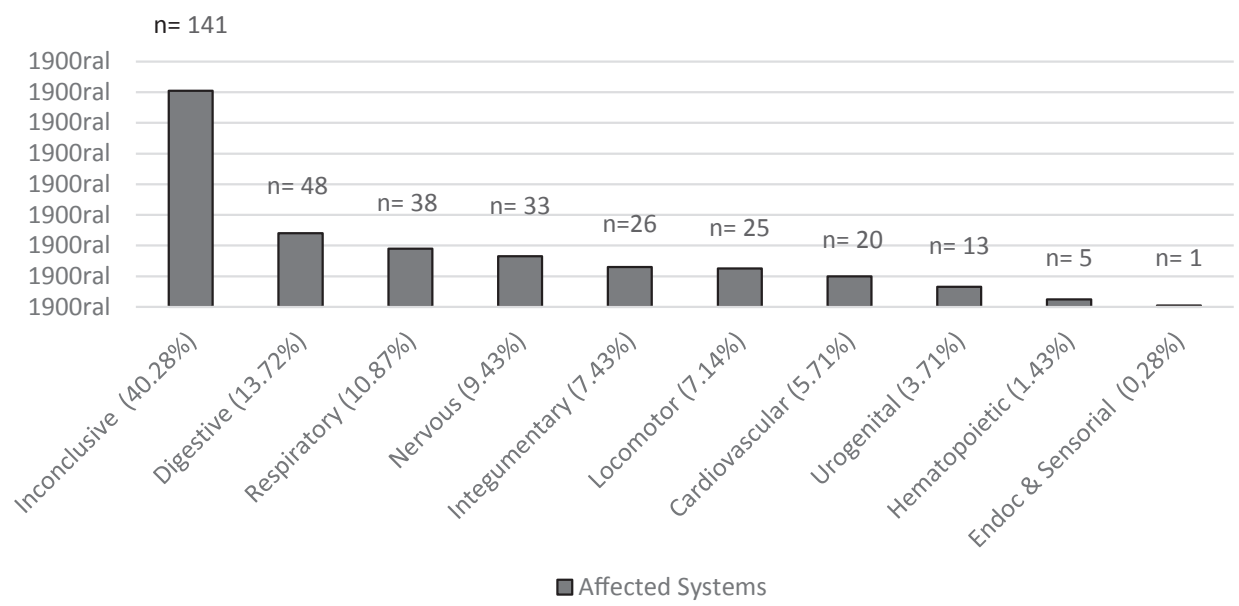

Figure 1 - Distribution of the number (n) of deaths of necropsied felines according to the affected system

Table 1 - Digestive system diseases directly related to feline deaths - Uberlândia, MG, Brazil - 1975-2011

\begin{tabular}{cc}
\hline Diagnoses & Number of cases (\%) \\
\hline Feline hepatic lipidosis & $9(18.76 \%)$ \\
Peritonitis & $6(12.5 \%)$ \\
Infectious feline & $4(8.34 \%)$ \\
Accute & $1(2.08 \%)$ \\
Granulomatous & $1(2.08 \%)$ \\
Hepatitis & $5(10.42 \%)$ \\
Helminthiasis & $4(8.34 \%)$ \\
Hepatic necrosis & $3(6.26 \%)$ \\
Stomatitis & $3(6.26 \%)$ \\
Chronic cholangitis & $2(4.16 \%)$ \\
Cholangiocarcinoma & $2(4.16 \%)$ \\
Cholangiohepatitis & $2(4.16 \%)$ \\
Cholestasis & $2(4.16 \%)$ \\
Enteritis & $1(2.08 \%)$ \\
Fecaloma & $1(2.08 \%)$ \\
Erosive gastritis & $1(2.08 \%)$ \\
Pancreatitis & $1(2.08 \%)$ \\
Gastroenteritis & $1(2.08 \%)$ \\
\hline ntestinal obstruction & $1(2.08 \%)$ \\
\hline
\end{tabular}

Rabies and intracerebral hemorrhage were the main causes of death related to the nervous system. Seven cats had rabies as their cause of death. In addition to these animals, other animals had clinical suspicion of rabies, but due to the lack of Negri bodies, other diseases as lymphocytic meningoencephalitis were defined as the
Table 2 - Respiratory system diseases directly related to feline deaths - Uberlândia, MG, Brazil - 1975-2011

\begin{tabular}{cc}
\hline Diagnoses & Number of cases (\%) \\
\hline Pneumonia & $12(31.57 \%)$ \\
Acute & $6(15.79 \%)$ \\
Lung abscess & $1(2.63 \%)$ \\
Mycotic granulomatous & $1(2.63 \%)$ \\
Hemorrhagic & $1(2.63 \%)$ \\
Lymphocytic & $1(2.63 \%)$ \\
Parasitic & $1(2.63 \%)$ \\
Pyogranulomatous & $1(2.63 \%)$ \\
Bronchopneumonia & $6(15.79 \%)$ \\
Acute serous & $2(4.16 \%)$ \\
Acute suppurative & $2(4.16 \%)$ \\
Parasitic & $2(4.16 \%)$ \\
Pulmonary edema & $6(15.80 \%)$ \\
Diaphragmatic hernia & $6(15.80 \%)$ \\
Pleuropneumonia & $2(4.16 \%)$ \\
Acute & $1(2.63 \%)$ \\
Chronic suppurative & $1(2.63 \%)$ \\
Bronchogenic carcinoma with & $1(2,63 \%)$ \\
omentum metastasis & $1(2,63 \%)$ \\
Cryptococcosis & $1(2,63 \%)$ \\
Thoracic empyema & $1(2,63 \%)$ \\
Nocardiosis & $1(2,63 \%)$ \\
\hline inotic Tracheobronchitis & $1(2,63 \%)$ \\
\hline
\end{tabular}

cause of death of the cats. Two of them, which have died due to intoxication, had as toxic agents involved the strychnine and the carbamate.

Integumentary system was the fourth most affected, with higher occurrences of carcinoma, followed by adenocarcinoma, chronic dermatitis, muscular abscess, 
fibroadenoma of the breast, and mastocytoma. Locomotor system was the fifth most affected one with causes of death of cats in this research. Among the causes, fibrous osteodystrophy was the major cause of death followed by fractures, traumatisms, and rickets. The main fracture reported was in the femur bone, followed by mandible, tibia, cervical vertebra, and sacral vertebra.

Concerning the cardiovascular system, the sixth system most related to death causes, shock was the main cause of deaths, being hypovolemic shock the most related cause. Urogenital system represented the seventh most related to deaths of cats and nephritis represented the major cause of deaths among the animals with urinary problems, while purulent metritis was the disease found in the reproductive system.

The systems with the lowest correlation with causes of death of felines are hematopoietic, endocrine, sensorial, and reproductive. In the hematopoietic system, feline leukemia prevailed as the main cause of death, and in the endocrine and sensorial systems the testified pathology was iridocyclitis. In the reproductive system, purulent metritis was the disease found. Some of the inconclusive diagnoses (104 animals - 73.75\%) presented clinical suspicion of rabies, however, without macroscopic lesions or microscopic findings that could lead to the confirmation of the disease.

\section{Discussion}

Since the number of cats in the routine of the veterinary hospital was smaller than that of dogs, the study period has been extended (1975 to 2011) in order to obtain 350 cats' necropsy medical records. Thus, considering the period, the number of necropsied felines in this study was small (350 animals in 36 years). This fact may be due to a lower adoption of cats as pets; the recurrent observation that cats die, mostly, away from their homes; the lack of interest of the owners about the cause of death and even to the lack of knowledge about the necropsy as a way to discover the cause of death to these pets (MACHADO; PAIXÃO, 2014).

It is known that epidemiological changes in the profile of diseases and pathogens can occur over time (THRUSFIELD, 2004). However, no significant variations were found in the disease profile evaluated in this study, probably due to cats' behavioral characteristics. Cats' behavior has already been addressed in the scientific literature, as well as its consequences for their survival (MACHADO; GENARO,
2010). In this respect, it is paramount to highlight that cats spend long spans of time away from home. This behavior may cause malnutrition, which is one of the main causes of hepatic lipidosis. (BARBERO, 2006; LITTLE, 2015). In addition, the aforementioned habit may favor contact with feline infectious peritonitis virus, another important cause of death observed in this study (ROSA et al., 2009).

A study performed by Gonçalves (2010) about causes of sudden death in cats and dogs showed that, among 60 reports analyzed concerning deaths of cats, $67 \%$ were males. Olsen and Allen (2001) also discovered a higher occurrence of sudden deaths in male cats. On the other hand, Xavier (2004), evaluating cases of intoxication by aldicarb, pointed its higher occurrence in female cats (45.23\%). This fact was also verified by Menezes et al. (2011) when evaluating death by intoxication, detecting that $60 \%$ of the cats were female. Based on this study and on the comparison with the cited bibliography, it is possible to notice that gender did not influence in the death causes of the examined felines.

Gonçalves (2010) noticed a higher occurrence of sudden deaths of cats from one to six years old (60\%); as well as Olsen and Allen (2001), who verified that 51.5\% of the animals were two years old or less. In this research, most of the dead animals were from 0 to 12 months old, which may be a consequence of the lack of basic care with these animals in their early years, as well as nonadministration of vaccines and incorrect nutritional diet, among other factors.

The occurrence of neoplasms in elderly cats is relatively common, as observed by Little (2015). This fact confirms the findings in this research, in which death caused by squamous cell carcinoma had a higher prevalence in cats between 10 and 12 years old.

In a study carried out in Lisbon (Portugal), Gonçalves (2010) verified a higher percentage of sudden death in breed cats (European Shorthair). This tendency is also observed in other countries, as verified in the study by O'Neill et al. (2014), in which the survival of half-breed cats in England was testified to be higher than in those of pure breed. These findings differ from those here reported, since there were higher death rates of half-breed cats (68.10\%). However, it is worth mentioning that most of the domiciled and errant felines in the region of the study are half-breed, which probably contributed to its higher occurrence.

As for the suggestive animals with feline hepatic lipidosis, many of them could be diagnosed with feline 
infectious peritonitis, as elucidated by Little (2015). Such disease in a non-effusive form causes feline hepatic lipidosis as consequence. Furthermore, this pathology presents a high frequency in felines and a high mortality rate (about 90\%) in untreated cats (BARBERO, 2006; LITLLE, 2015).

Gonçalves (2010) verified that most sudden deaths in felines were motivated by respiratory diseases (30\%), pneumonia being the most frequent (44\%), followed by acute pulmonary edema (28\%). Similarly, Batista et al. (2016) found that infectious diseases are the main causes of death of cats and dogs. These findings confirm the present study, in which pneumonia has also been shown as a frequent cause of death of these animals. Among possible causes of pneumonia and pulmonary edema in these felines, the feline leukemia virus (FeLV) is emphasized, since the majority of cats in this research were young, with no vaccination background and with access to the street. However, only $1.43 \%$ of the feline deaths could be directly related to FeLV, which raises the hypothesis that this pathology may be underdiagnosed at the veterinary clinic.

Diaphragmatic hernia was another important cause of death found amongst felines in this study. It is believed to be due to traumatisms, which may also have contributed in the cases of fracture, intracerebral hemorrhage, diaphragmatic rupture, and hypovolemic shock that were analyzed. In a previous study, a similar result was observed by Rochlitz (2004), who noticed an increase in the number of animals that were attended due to automobile accidents, falls, and fights with other animals or even with lesions intentionally induced by humans.

As for the cases of death with the etiology related to the nervous system, considering that there were some unconfirmed suspicions of rabies, the hypothesis of underdiagnosis rises again, since positive cases can occur as a consequence of this disease and Negri bodies may not be found in a histopathological analysis (ROLIM, 2011).

Differently from what has been verified in previous studies (XAVIER, 2004; MENEZES et al., 2011), only two cats died due to toxic agents in this study. Considering that evaluations about forensic necropsies in animals reveal a high rate of intoxication cases in domestic cats (SALVAGNI et al., 2013; MACHADO; PAIXÃO, 2014), probably the small number of cases verified in this study were due to the lack of knowledge by the owners about necropsy as a diagnostic tool, during the assessed period.

Squamous cell carcinoma, a malign neoplasm of epidermal origin relatively common in cats, was the main cause of death of felines involving the integumentary system. This finding is in agreement with the literature, since this neoplasm represents $15 \%$ of feline skin tumors and at least $70 \%$ of feline oral malignant tumors. $31 \%$ had metastatic disease in the submandibular lymph nodes and $10 \%$ had evidence of thoracic metastasis (LITLLE, 2015).

Fibrous osteodystrophy, observed here as the main pathology of the locomotor system related to death, may have happened due to acute hyperparathyroidism, since according to Forrest (2014), in this condition, demineralization occurs followed by fibrous tissue hyperplasia. Furthermore, clinical manifestations of bone demineralization due to chronic kidney disease are extremely rare among cats and dogs (NELSON; COUTO, 2015).

Diseases in the cardiovascular system were the sixth most frequent cause of death in the assessed felines, differently from what had been observed by Gonçalves (2010) and Olsen and Allen (2001). In these researches cardiac diseases were the second most frequent cause of death of cats, and cardiomyopathy was the main responsible for deaths.

Although cats are frequently affected by urinary tract diseases (NELSON; COUTO, 2015), the frequency observed in this study was relatively low (12 in 350 cases). However, in previous years Wouters et al. (1998) also verified a low occurrence (13 cases in 154 necropsies carried out in cats in six years).

It was not possible to determine the cause of death in $40.28 \%$ of cats, since the diagnosis was inconclusive. This is due to the inexistence of sufficient data that could contribute to define the cause of death, which may have occurred due to the lack of complementary exams performed by the owners or even to the condition of the animal at the moment of necropsy (autolysis, for instance). Nevertheless, the impossibility of identification of the cause of death is common in this type of analysis, as it was detected in $13 \%$ of the animals evaluated by Gonçalves (2010) and in $12.7 \%$ of the animals analyzed by Olsen and Allen (2001).

\section{Conclusion}

Studies about the causes of death in felines are rare and in the scientific literature only researches about specific etiologies can be found. Covering all the causes of death in domestic cats during this period, we verified that the digestive system was the system most frequently related 
to the death of these cats, and feline hepatic lipidosis was the most frequent disease. Future research should be done in order to compare the data obtained here. The analysis of these data can help professional veterinarians in the adoption of control and prevention measurements of those diseases.

\section{References}

BARBERO, C. C. Lipidose hepática felina. 2006. $52 \mathrm{f}$. Monografia (Especialização) - Universidade Castelo Branco, Rio de Janeiro, 2006.

BATISTA, E. K. F.; PIRES, L. V.; MIRANDA, D. F. H.; ALBUQUERQUE, W. R.; CARVALHO, A. R. M.; SILVA, L. S.; SILVA, S. M. M. S. Estudo retrospectivo de diagnósticos post-mortem de cães e gatos necropsiados no Setor de Patologia Animal da Universidade Federal do Piauí, Brasil de 2009 a 2014. Brazilian Journal of Veterinary Research and Animal Science, v. 53, n. 1, p. 88-96, 2016. doi: 10.11606/issn.1678-4456.v53ilp88-96.

BENTUBO, H. D. L.; TOMAZ, M. A.; BONDAN, E. F.; LALLO, M. A. Expectativa de vida e causas de morte em cães na área metropolitana de São Paulo (Brasil). Ciência Rural, v. 37, n. 4, p. 1021-1026, 2007. doi: 10.1590/S010384782007000400016 .

COARSEY, M. D.; WOLDEMESKEL, M. Basic necropsy procedures. In: BASSERT, J. M.; BEAL, A. D.; SAMPLES, O. M. McCurnin's clinical textbook for veterinary technicians. 9. ed. St. Louis, MO: Elsevier, 2017. p. 518-539.

FIGHERA, R. A.; SOUZA, T. M.; SILVA, M. C.; BRUM, J. S.; GRAÇA, D. L.; KOMMERS, G. D.; IRIGOYEN, L. F.; BARROS, C. S. L. Causas de morte e razões para eutanásia de cães da mesorregião do Centro Ocidental Rio-Grandense (1965-2004). Pesquisa Veterinária Brasileira, v. 28, n. 4, p. 223-230, 2008. doi: 10.1590/S0100-736X2008000400005.

FORREST, L. J. Cavidades craniana e nasal: cães e gatos. In: THRALL, D. E. (Ed.). Diagnóstico de radiologia veterinária. 6. ed. Rio de Janeiro: Elsevier, 2014. p. 117.

LITTLE, S. E. (Ed.). August's consultations in feline internal medicine. St. Louis, MO: Elsevier, 2015. v. 7. $1088 \mathrm{p}$.

\section{Acknowledgements}

The authors would like to acknowledge the contribution of the Veterinary Hospital of the Federal University of Uberlândia to the development of the project and also to thank the department of animal pathology of the abovementioned University.

GRIGALEVICIUS, S.; ANDRADE, M. F.; MINGATES, D. H.; CARVALHO, R. B.; BOCHIO, M. M.; ALMEIDA, M. M. Frequência das causas de óbito/eutanásia no canil do Centro de Controle de Zoonoses do município de São Paulo (CCZ-SP) no ano de 2013. Revista de Educação Continuada em Medicina Veterinária e Zootecnia do CRMV-SP, v. 13, n. 2, p. 98, 2015. Available from: <https:// goo.gl/3WxLXk>. Viewed: 18 Dec. 2017.

GONÇALVES, M. P. R. P. Morte súbita em cães e gatos: estudo retrospectivo de 213 casos (2000-2009). 2010. $97 \mathrm{f}$. Dissertação (Mestrado) - Universidade Técnica de Lisboa, Lisboa, 2010.

MACHADO, J. C.; GENARO, G. Comportamento exploratório em gatos domésticos (Felis silvestris catus Linnaeus, 1758): uma revisão. Archives of Veterinary Science, v. 15, n. 2, p. 107-117, 2010. doi: 10.5380/avs. v15i2.17199.

MACHADO, J. C.; PAIXÃO, R. L. A representação do gato doméstico em diferentes contextos socioculturais e as conexões com a ética animal. Revista Internacional Interdiscipliar INTERthesis, v. 11, n. 1, p. 231-253, 2014. doi: 10.5007/1807-1384.2014v11n1p231.

MANTEIGAS, F.; GODINHO, A.; ALMEIDA, P. Causas de mortalidade em gatos com mais de nove anos: estudo retrospectivo de cem casos. Revista Lusófona de Ciência e Medicina Veterinária, v. 6, p. 47-57, 2013.

MENEZES, R. S.; ALMEIDA, E. C. P; FERREIRA, A. M. R. Análise retrospectiva de casos de intoxicação fatal em cães e gatos diagnosticados em necropsias no período de 2004 a 2011. In: CONGRESSO MEDVEP DE ESPECIALIDADES VETERINÁRIAS, 2011, Rio de Janeiro. Proceedings... Rio de Janeiro: Medvep, 2011. v. 1, p. 1-3. 
NELSON, R. W; COUTO, C. G. Medicina interna de pequenos animais. 5. ed. Rio de Janeiro: Elsevier, 2015. 1512 p.

O’NEILL, D. G.; CHURCH, D. B.; MCGREEVY, P. D.; THOMSON, P. C.; BRODBELT, D. C. Longevity and mortality of cats attending primarycareveterinary practices in England. Journal of Feline Medicine and Surgery, v. 17, n. 2, p. 125-133, 2014. doi: 10.1177/1098612X14536176.

OLSEN, T. F.; ALlEN, A. L. Causes of sudden and unexpected death in cats: a 10 year retrospective study. The Canadian Veterinary Journal, v. 42, n. 1, p. 61-62, 2001. Available from: <https://goo.gl/7nX1EV>. Viewed: 18 Dec. 2017.

ROCHLITZ, I. Clinical study of cats injured and killed in road traffic accidents in Cambridgeshire. Journal of Small Animal Practice, v. 45, n. 8, p. 390-394, 2004. doi: 10.1111/ j.1748-5827.2004.tb00253.x.

ROLIM, B. N. Diagnóstico da raiva: técnica de coleta de medula cervical e implantação da metodologia no estado do Ceará - Brasil. 2011. 145 f. Tese (Doutorado) Universidade Estadual do Ceará, Fortaleza, 2011.

ROSA, B. R. T.; FERREIRA, M. M. G.; AVANTE, M. L.; MARTINS, I. S.; FILHO, D. Z.; BISSOLI, E. D. G. Peritonite infecciosa felina. Revista Científica Eletrônica de Medicina Veterinária, v. 7, n. 12, 2009. Available from: <https:/goo.gl/THX4Wv>. Viewed: 18 Dec. 2017.
SALVAGNI, F. A.; SIQUEIRA, A.; MARIA, A. C. B. E.; MESQUITA, L. P.; MAIORKA, P. C. Necropsias documentadas com fins periciais em animais: estudo de 207 casos entre 2009 e 2013. Archives of Veterinary Science, v. 18, p. 367-369, 2013. Supplement 2. doi: 10.5380/ avs.v18i3.33866.

THRUSFIELD, M. Epidemiologia veterinária. 2. ed. São Paulo: Roca, 2004. 558 p.

TRAPP, S. M.; IACUZIO, A. I.; BARCA JUNIOR, F. A.; KEMPER, B.; SILVA, L. C.; OKANO, W.; TANAKA, N. M.; GRECCO, F. C. A. R.; CUNHA FILHO, L. F. C.; STERZA, F. A. M. Causas de óbitos e razões para eutanásia em uma população hospitalar de cães e gatos. Brazilian Journal of Veterinary Research and Animal Science, v. 47, n. 5, p. 395-402, 2010. doi: 10.11606/issn.1678-4456. bjvras.2010.26821.

WOUTERS, F.; BARROS, C. S. L.; WOUTERS, A. T. B.; KOMMERS, G. D. Síndrome urológica felina: 13 casos. Ciência Rural, v. 28, n. 3, p. 497-500, 1998. doi: 10.1590/ S0103-84781998000300024.

XAVIER, F. G. Intoxicação por aldicarb ("chumbinho") em cães e gatos: estudo das alterações post mortem macroscópicas e diagnóstico toxicológico por meio da cromatografia em camada delgada em amostras de conteúdo estomacal. 2004. 192 f. Dissertação (Mestrado) - Faculdade de Medicina Veterinária e Zootecnia, Universidade de São Paulo, São Paulo, 2004. 